\title{
PENGATURAN PENDAFTARAN BADAN USAHA BUKAN BADAN HUKUM MELALUI SISTEM ADMINISTRASI BADAN USAHA
}

\author{
Putu Devi Yustisia Utami \\ Fakultas Hukum Universitas Udayana \\ e-mail : deviyustisia27@gmail.com
}

\begin{abstract}
Abstrak
Istilah Perseroan Komanditer, Firma dan Persekutuan Perdata sudah tidak asing lagi bagi kita. Dasar hukum pendirian CV, Firma dan Persekutuan Perdata adalah berdasarkan KUHD dan KUHPerdata. Berdasarkan pasal 23 KUHD, pendaftaran pendirian CV, Firma dan Persekutuan Perdata dilakukan di Kepaniteraan Pengadilan Negeri. Akan tetapi, saat ini pemerintah telah menerbitkan Peraturan Menteri Hukum dan HAM Nomor 17 Tahun 2018 tentang Pendaftaran CV, Firma dan Persekutuan Perdata dimana pendaftarannya mirip dengan pendaftaran badan usaha berbadan hukum yaitu dilakukan kepada Menteri melalui Sistem Administrasi Badan Usaha (SABU) secara online. Ini menyebabkan adanya ketidaksesuaian norma mengenai pendaftaran pendirian badan usaha bukan badan hukum. Berdasarkan paparan tersebut penulis menemukan permasalahan yaitu Bagaimanakah pengaturan mengenai badan usaha bukan badan hukum dalam peraturan perundang- undangan yang berlaku di Indonesia dan Apa akibat hukum bagi badan usaha bukan badan hukum yang berdiri sebelum berlakunya Permenkumham No. 17 tahun 2018 yang tidak mendaftarkan dirinya pada Sistem Administrasi Badan Usaha (SABU). Jenis penelitian yang digunakan adalah penelitian hukum normatif dengan pendekatan perundang- undangan (Statute Approach) dan pendekatan analisis konsep (Analytical Concept Approach). Kesimpulannya adalah berdasarkan asas lex posterior derograt legi priori, dalam hal terjadi dualisme pengaturan pendaftaran CV, Firma dan Persekutuan Perdata, ketentuan hukum yang dipergunakan adalah KUHD dan KUHPerdata.
\end{abstract}

Kata kunci : Badan usaha, CV, Firma, Persekutuan Perdata, SABU.

\begin{abstract}
The terms of the Commanditer Venootschap, Firm and Maatschaap are familiar to us. The legal basis for the establishment of Commanditer Venootschap, Firm and Maatschaap is based on Trade Law Code and Civil Code. Based on article 23 of the Trade Law Code, registration of the establishment of a Commanditer Venootschap, Firm and Maatschaap is conducted in the Registrar's Office of the District Court. However, currently the government has issued Minister of Law and Human Rights Regulation Number 17 of 2018 concerning Commanditer Venootschap, Firm and Maatschaap where the registration is similar to the registration of legal entity company that is carried out to the Minister through an Online Business Administration System (SABU). This has led to incompabilitty norms regarding the
\end{abstract}


registration for the establishment of a non legal entity company. Based on the explanation, the author found a problem, namely: What is the regulation regarding non legal entity company in the applicable laws and regulations in Indonesia and What are the legal consequences for business entities not legal entities that stand before the entry into force of Minister of Law and Human Rights Regulation Number 17 of 2018 which does not register with the Business Entity Administration System $(S A B U)$. The research type used is normative legal research, use a Statute Approach and the Analytical Concept Approach. The conclusion is, based on the principle of lex posterior derograt legi priori, in the event of a dualism in the regulation of registration of Commanditer Venootschap, Firm and Maatschaap, the legal provisions used are KUHD and Civil Code.

Keywords: Companies, CV, Firm, Maatschap, SABU.

\section{Pendahuluan}

Masyarakat dalam menjalani kehidupannya harus melakukan sesuatu untuk memenuhi kebutuhan hidupnya, salah satu hal yang dapat dilakukan adalah dengan bekerja atau berusaha. Masyarakat dapat melakukan atau menjalankan usaha apa saja, sepanjang hal tersebut tidak melanggar kesopanan, kesusilaan dan ketentuan peraturan perundangundangan. Dalam memenuhi kebutuhan hidupnya ada masyarakat yang bekerja menjadi karyawan di suatu perusahaan tertentu atau bahkan ada masyarakat yang berwiraswasta dengan mendirikan perusahaannya sendiri. Istilah perusahaan sudah tidak asing lagi di telinga kita semua. Istilah perusahaan lekat sekali dengan istilah perdagangan, dimana istilah perusahaan tercantum di dalam Kitab Undang- Undang Hukum Dagang (untuk selanjutnya disebut KUHD), namun pengertian dari perusahaan itu sendiri tidak dapat kita temui dalam KUHD. Pada pasal 1 huruf b UU No. 3/ 1982 tentang Wajib Daftar Perusahaan perusahaan didefinisikan sebagai bentuk usaha yang dijalankan oleh seseorang secara terus menerus, bersifat tetap dan harus didirikan di wilayah Indonesia, dengan tujuan utama untuk memperoleh laba.

Di Indonesia sendiri terdapat beragam bentuk- bentuk badan usaha baik yang bersifat perorangan, persekutuan maupun badan hukum seperti Perusahaan Dagang (PD), Comanditter Vennootschap (CV), Firma, Persekutuan Perdata (Maatschap), Perseroan Terbatas (PT) dan Koperasi. Perseroan Komanditer, Persekutuan Perdata dan Firma adalah badan usaha bukan badan hukum, sedangkan Perseroan Terbatas dan Koperasi merupakan badan usaha berbadan hukum. (Abdulkadir Muhammad, 1999:2)

Begitu banyaknya jenis perusahaan atau badan usaha di masyarakat maka diperlukan 
adanya pengaturan atas perusahaan- perusahaan tersebut dalam suatu aturan hukum. Bentuk perusahaan perseorangan belum ada pengaturannya dalam undang- undang, pengaturan perusahaan perseorangan berkembang sesuai dengan kebutuhan masyarakat sebagai pengusaha yang dalam praktiknya dibuat secara tertulis di hadapan Notaris. (Abdulkadir Muhammad, 1999:2)

Untuk bentuk badan usaha yang berbadan hukum seperti PT dan Koperasi telah diatur dalam peraturan perundang- undangan khusus. PT diatur dalam UU Perseroan terbatas yaitu UU No. 40/ 2007 (yang selanjutnya disebut dengan UUPT) dan Koperasi diatur dalam UU. No. 25 / 1992 tentang Perkoperasian (untuk selanjutnya disebut dengan UU Koperasi), sedangkan pengaturan mengenai CV, Firma dan Persekutuan Perdata sebagai badan usaha bukan badan hukum sebelum tahun 2018 masih diatur dalam ketentuan perundang- undangan peninggalan Belanda yaitu dalam ketentuan yang terdapat dalam Kitab Undang Undang Hukum Perdata (untuk selanjutnya disebut KUHPerdata) dan di dalam KUHD.

Pendirian perusahaan perseorangan berupa Perusahaan Dagang (PD) lebih mudah dan sederhana dibandingkan dengan badan usaha bukan badan hukum dan badan usaha badan hukum. Dalam pendirian badan usaha perseorangan hanya didirikan seorang pengusaha sehingga tidak diperlukan adanya perjanjian. Pengusaha yang akan mendirikan perusahaan perorangan cukup membuat anggaran dasar perusahaan yang kemudian dituangkan dalam akta pendirian yang dibuat oleh Notaris (Abdulkadir Muhammad, 1999:48). Pada perusahaan atau badan usaha yang berbadan hukum akta pendirian perusahaan tersebut perlu memperoleh pengesahan dari Menteri terkait. Untuk pengesahan PT dilakukan oleh Menteri Hukum dan Hak Asasi Manusia sedangkan untuk pengesahan Koperasi dilakukan oleh Menteri Koperasi.

Sebelum tahun 2018, pendirian perusahaan atau badan usaha bukan badan hukum seperti CV, Firma diatur dalam KUHD, sedangkan pendirian Persekutuan Perdata diatur dalam KUHPerdata yang mana kedua produk hukum Belanda ini juga masih berlaku sampai dengan saat ini. Berdasarkan ketentuan KUHD dan KUHPerdata syarat pengesahan dari Menteri Hukum dan HAM dalam pendirian $\mathrm{CV}$, Firma dan Persekutuan Perdata tidak diperlukan karena CV, Firma dan Persekutuan Perdata bukan merupakan perusahaan atau badan usaha badan hukum sehingga hanya perlu dilakukan pendaftaran di kepaniteraan Pengadilan Negeri (Abdulkadir Muhammad, 1999:56)

Pada bulan Juni tahun 2018 pemerintah mengeluarkan Peraturan Pemerintah Nomor 24 
Tahun 2018 tentang Pelayanan Perizinan Berusaha Terintegrasi Secara Elektronik (untuk selanjutnya disebut PP Perizinan Berusaha Elektronik), dimana pada pasal 15 sampai dengan pasal 17 mengatur mengenai $C V$, Firma dan Persekutuan Perdata. Dalam PP Perizinan Berusaha Elektronik ini badan usaha yang berbentuk CV, Firma dan Persekutuan Perdata diharuskan untuk dilakukan pendaftaran kepada pemerintah pusat yaitu kementerian yang menyelenggarakan urusan pemerintahan di bidang hukum yang dalam hal ini adalah Kementerian Hukum dan Hak Asasi Manusia (Kemenkumham). Untuk mengimbangi Peraturan Pemerintah mengenai Perizinan Berusaha Elektronik, kemudian Kemkumham pada bulan Juli 2018 juga mengeluarkan Peraturan Menteri Hukum dan Hak Asasi Manusia Nomor 17 Tahun 2018 (untuk selanjutnya disebut Permenkumham No. 17/2018) tentang Pendaftaran Persekutuan Komanditer, Persekutuan Firma dan Persekutuan Perdata. Permenkumham No. 17/2018 ini pada prinsipnya mengatur mengenai adanya kewajiban bagi para pelaku usaha yang memiliki badan usaha yang berbentuk $C V$, Firma dan Persekutuan Perdata untuk melakukan pendirian dan pendaftaran perusahaannya pada Menteri melalui Sistem Administrasi Badan Usaha (SABU).

Dari paparan diatas terlihat adanya dua isu hukum normatif terkait dengan dualisme pengaturan mengenai badan usaha non badan hukum yang berbentuk Persekutuan Komanditar, Firma dan Persekutuan Perdata yaitu sebagai berikut:

Pertama, adanya tumpang tindih peraturan hukum mengenai Firma, Persekutuan Komanditer dan Persekutuan Perdata, dimana di satu sisi pengaturan mengenai Firma, Persekutuan komanditer dan Persekutuan Perdata masih diatur melalui KUHD dan KUHPerdata, namun kemudian di sisi lain juga berlaku Permenkumham No. 17/ 2018. Jika kita perhatikan kembali bahwa Permenkumham No. 17/ 2018 tersebut tidak mencabut keberlakuan dari KUHD dan KUHPerdata sepanjang yang menyangkut Firma, Persekutuan Perdata dan Persekutuan Perdata, sehingga peraturan mengenai $\mathrm{CV}$, Firma dan Persekutuan Perdata yang diatur dalam pasal 23 KUHD dan pasal 1618 KUHPerdata tersebutpun masih berlaku hingga saat ini.

$$
\text { Kedua, terdapat }
$$

ketidaksesuaian (konflik) pengaturan pendaftaran Firma, Persekutuan Perdata dan Persekutuan Komanditer sebagaimana diatur dalam pasal 23 KUHD dengan Permenkumham No. 17/ 2018. Dimana pada pasal 23 KUHD mengatur bahwa pendaftaran $\mathrm{CV}$ dan Firma cukup di Kepaniteraan Pengadilan Negeri dan pendaftaran Persekutuan Perdata yang tidak diatur secara jelas 
dalam pasal 1618 KUHPerdata mengikuti pendaftaran $\mathrm{CV}$ dan Firma, namun disisi lain Permenkumham No. 17/ 2018 mengatur bahwa Firma, CV dan Persekutuan Perdata harus didaftarkan kepada Menteri melalui Sistem Administrasi Badan Usaha (SABU).

Berdasarkan paparan yang telah diuraikan pada latar belakang diatas, penulis menyusun suatu karya tulis yang diberi judul "Pengaturan Pendaftaran Badan Usaha Bukan Badan Hukum Melalui Sistem Administrasi Badan Usaha (Sabu)".

\section{Perumusan Masalah}

Adapun permasalahan yang penulis kemukakan dalam penulisan karya tulis ini adalah sebagai berikut :

1. Bagaimanakah pengaturan mengenai badan usaha bukan badan hukum dalam peraturan perundangundangan yang berlaku di Indonesia?

2. Apa akibat hukum bagi badan usaha bukan badan hukum yang berdiri sebelum berlakunya Peraturan Menteri Hukum dan HAM Nomor 17 tahun 2018 yang tidak mendaftarkan dirinya pada Sistem Administrasi Badan Usaha (SABU) ?

\section{Metode Penelitian}

Jenis penelitian yang dipergunakan dalam penulisan karya tulis ilmiah ini adalah penelitian hukum normatif yang diawali dengan adanya isu hukum berupa ketidaksesuaian dan ketumpang tindihan norma yang mengatur mengenai badan usaha bukan badan hukum di Indonesia. Jenis pendekatan yang dipergunakan adaah pendekatan perundang- undangan (Statute Approach) dan pendekatan analisa konsep hukum (Analitycal and Conceptual Approach). Dalam penulisan karya ilmiah ini penulis menggunakan sumber bahan hukum primer, bahan hukum sekunder dan bahan hukum tersier. Dimana bahanbahan hukum yang dikumpulkan oleh penulis adalah menggunakan teknik studi kepustakaan (library research), kemudian dianalisa oleh penulis dengan teknik deskripsi, sistematisasi, evaluasi, pada akhirnya dengan menggunakan teknik argumentasi penulis dapat menarik suatu kesimpulan.

\section{Pengertian Perusahaan}

Istilah perusahaan dipergunakan dalam KUHD, akan tetapi KUHD sendiri tidak memberikan pengertian dan definisi mengenai apa yang dimaksud dengan perusahaan. Purwosutjipto berpendapat bahwa tidak adanya pengertian dan penafsiran resmi atas pengertian perusahaan bertujuan agar pengertian perusahaan tersebut dapat berkembang sesuai dengan perkembangan perusahaan itu sendiri di masyarakat (Gatot Supramono, 2007:2). Oleh sebab itu maka terdapat berbagai pendapat dari para sarjana mengenai definisi dan dari apa itu perusahaan. 
Polak menambahkan bahwa suatu kegiatan yang dilakukan tersebut baru dapat dinyatakan suatu perusahaan apabila terdapat perhitungan laba rugi yang dapat diperkirakan dan dicatat di dalam suatu pembukuan (Abdulkadir Muhammad, 1999:7).

Meskipun telah banyak sekali sarjana yang memberikan pengertian dan definisi apa itu perusahaan, akan tetapi ternyata pendapat para sarjana tersebut masih memiliki kelemahan karena tidak membahas mengenai pengertian perusahaan sebagai suatu badan usaha. Dalam UU No. 3/1982 tentang Wajib Daftar Perusahaan dapat dilihat adanya beberapa unsur penting dalam suatu perusahaan yaitu sebagai berikut :

1) Bentuk usaha berupa badan usaha atau organisasi;

2) Jenis usaha bersifat tetap dan dilakukan secara terus menerus;

3) Bekerja di wilayah Negara Republik Indonesia;

4) Memiliki tujuan untuk memperoleh keuntungan atau laba.

\section{Jenis- Jenis Badan Usaha}

Dalam suatu perusahaan terdapat pihak yang menjalankan perusahaan yang disebut dengan pengusaha. Pengusaha dapat berupa satu orang (individual), beberapa orang (partnership) dalam bentuk persekutuan dan berbentuk badan hukum (corporate body) (Abdulkadir Muhammad, 1999:56). Seperti yang telah disebutkan pada awal tulisan ini bahwa di Indonesia terdapat berbagai jenis badan usaha, yang sebetulnya mengadopsi bentuk usaha yang ada di Belanda yaitu Perusahaan Perorangan/ Perusahaan Dagang (PD), Perseroan Komanditer (Comanditter Venootschap), Firma, Persekutuan Perdata (Maatschaap), Perseroan Terbatas, Yayasan, Koperasi (Johannes Ibrahim, 2013:21-24). Sadono Sukirno memberikan pendapat bahwa, perusahaan dibedakan menjadi perusahaan perserorangan, perkongsian (partnership), dan perseroan terbatas (corporation). Zainal Asikin menyatakan bahwa ada berbagai jenis badan usaha yang pada umumnya diuraikan adalah perusahaan perorangan, badan usaha yang berbentuk persekutuan, dan badan usaha yang berbadan hukum (korporasi) (Sadono Sukirno, Dkk., 2017: 34).

Oleh karena terdapat begitu banyaknya jenis perusahaan yang sangat beragam, maka dilakukan klasifikasi perusahaan sebagai berikut:

1. Dari segi jumlah pemilik, maka perusahaan diklasifikasikan menjadi :

- Perusahaan perseorangan yaitu perusahaan yang didirikan dan dimiliki satu individu, yang pada prakteknya seringkali merupakan perusahaan keluarga;

- Perusahaan persekutuan, yang didirikan beberapan orang yang saling 
bekerjasama dalam suatu persekutuan.

2. Dari status pemiliknya, perusahaan diklasifikasikan menjadi :

-Perusahaan swasta yaitu perusahaan yang didirikan dan dimiliki oleh swasta; dan

-Perusahaan negara atau yang biasa disebut dengan Badan Usaha Milik Negara (BUMN) (Abdulkadir Muhammad, 1999:56).

3. Dari segi bentuk hukum sendiri jenis- jenis badan usaha tersebut dapat dibagi menjadi dua yaitu :

-badan usaha yang berbentuk badan hukum, dan;

-badan usaha bukan badan hukum.

( I.G.Rai Widjaja, 2007: 2).

Adapun yang termasuk perusahaan yang berbadan hukum yaitu:

- Perseroan Terbatas;

- Koperasi;

- Badan- badan usaha lain yang dinyatakan sebagai badan hukum dan memenuhi kriteria sebagai badan hukum (I.G.Rai Widjaja, 2007:2).

Dalam buku- buku atau literatur hukum, terdapat tiga macam perkumpulan yang tidak termasuk dalam katagori badan hukum, yaitu :

- Persekutuan

Perdata (Maatschap)

- Firma;

- Comaanditer Venootschap (CV); (Richard Burton Simatupang, 2007:10).
Pengaturan Badan Usaha Bukan

Badan Hukum Berdasarkan Produk Hukum Belanda.

Sebagaimana telah dibahas sebelumnya bahwa badan usaha bukan badan hukum terdiri dari $\mathrm{CV}$, Firma dan Persekutuan Perdata. Badan usaha bukan badan hukum diatur melalui :
a. Kitab Undang- Undang Hukum Perdata (KUHPerdata), dan;

b. Kitab Undang- Undang Hukum Dagang (KUHD).

Baik KUHPerdata dan KUHD sama- sama diundangkan berdasarkan Staatsblad Tahun 1874 Nomor 23 dan telah dikodifikasikan maupun di bukukan. (I.G.Rai Widjaja, 2007: 11).

Berdasarkan pengaturan badan usaha bukan badan hukum yang diatur di dalam KUHD dan KUHPerdata, terdapat perbedaan yang sangat signifikan jika dibandingkan dengan perusahaan badan hukum. Pada badan usaha bukan badan hukum hanya diperlukan kesepakatan para pihak, sedangkan syarat pengesahan akta pendirian oleh pemerintah tidak diperlukan, tanpa adanya formalitas, pendaftaran dan tanpa perlu adanya pengumuman (Richard Burton Simatupang , 2007:10).

Berikut ini akan dibahas satupersatu mengenai badan usaha bukan badan hukum beserta dasar hukumnya sebagaimana diatur dalam KUHD dan KUHPerdata. 


\section{Firma}

Dasar hukum Firma (vennootschap onder eene firma) masih menggunakan KUHD, dimana diatur dalam Bagian Kedua Bab Ketiga KUHD yang dicampur dengan ketentuan Persekutuan Komanditer pada pasal 16- 35 KUHD. Sebagaimana ketentuan dalam pasal 16 KUHD "Perseroan Firma adalah suatu perseroan yang didirikan untuk melakukan suatu usaha dibawah satu nama bersama". Suatu persekutuan atau perseroan baru dapat disebut dengan Firma apabila memenuhi syarat- syarat untuk menjalankan perusahaannya menggunakan nama bersama (Abdulkadir Muhammad, 1999:50).

Dalam perseroan firma setiap peseronya tanpa terkecuali berhak untuk bertindak, mengeluarkan dan menerima uang atas nama perseroan, dan mengikat perseroan dengan pihak ketiga dan sebaliknya. Berdasarkan ketentuan sebagaimana diatur dalam KUHD yang masih berlaku sampai dengan saat ini, yaitu pada pasal 22 dan 23, bahwa pendirian Firma dilakukan dengan akta otentik, namun pendirian firma bisa saja dibuat dengan tanpa akta autentik, sebab tidak ada keharusan untuk itu, akan tetapi demi kepentingan pihak ketiga akta otentik tetap diperlukan. Pendaftaran firma dilakukan dengan mendaftarkan akta firma tersebut dalam register di Kepaniteraan Pengadilan Negeri. Kemudian berdasarkan ketentuan pasal 28 KUHD, bahwa para pesero wajib untuk melakukan pengumuman atas akta firma tersebut di dalam Berita Negara.

Selama pendaftaran dan pengumuman belum berlangsung maka akibat hukumnya bagi pihak ketiga adalah sebagai berikut :

1. Firma dianggap menjalankan segala macam urusan perniagaan;

2. Didirikan dalam waktu tidak terbatas;

3. Tidak ada sekutu yang dikecualikan untuk bertindak dan menandatangani surat bagi persekutuan (Abdul, R., Salimar, 2005:102).

\section{Comaanditer Venootschap (CV)}

Persekutuan Komanditer atau CV adalah firma yang memiliki satu atau lebih sekutu diam. Yaitu sekutu yang hanya menyerahkan uang, barang atau tenaga sebagai pemasukan dalam suatu persekutuan (Abdulkadir Muhammad, 1999:55). Sekutu diam atau komanditer disebut silent partner, yang berhak untuk mengawasi pengurusan persekutuan komanditer secara intern.

Pendirian CV tidak diatur secara khusus di dalam KUHD, akan tetapi oleh karena CV merupakan Firma maka untuk pengaturan $\mathrm{CV}$ juga diberlakukan ketentuan pasal 22 dan 23 KUHD. CV didirikan dengan membuat anggaran dasar melalui akta pendirian yang dibuat oleh dan dihadapan Notaris, didaftarkan di PN dan 
diumumkan dalam Tambahan Berita Negara.

Syarat pengesahan dari Kementerian Hukum dan HAM tidak diperlukan karena CV sama halnya dengan Firma bukan merupakan badan hukum, dimana tidak ada pemisahan harta kekayaan antara harta kekayaan CV dengan harta kekayaan pribadi para sekutu komplementer.

\section{Persekutuan \\ Perdata \\ (Maatschap) \\ Berbeda dengan $\mathrm{CV}$ dan} Firma yang diatur di dalam KUHD, Persekutuan perdata atau yang merupakan terjemahan dari Burgerlijke Maatschap diatur dalam KUHPerdata yaitu pasal 1618 sampai dengan 1646 (Gatot Supramono, 2007:13). Istilah Maatschap sendiri dalam bahasa Indonesia diterjemahkan dengan Persekutuan atau Perseroan. Sebagaimana diatur dalam pasal 1618 KUHPerdata, persekutuan perdata didirikan berdasar persetujuan 2 orang atau lebih untuk memasukkan uang, barang- barang ataupun kerajinan yang berupa tenaga dan keterampilan ke dalam persekutuan Maatschap (I.G.Rai Widjaja, 2007: 36).

Pendirian Maatschap harus didirikan oleh minimal dua orang sekutu yang sesuai dengan definisinya didirikan melalui perjanjian, dan dapat didirikan dalam perjanjian sederhana tanpa perlu adanya pengajuan secara formal atau tidak diperlukan adanya persetujuan pemerintah. Pendiriannya cukup secara lisan namun dapat juga berdasarkan akta pendirian, baik tertulis ataupun lisan atau bahkan dinyatakan melalui tindakantindakan atau perbuatanperbuatan para pihak ( I.G.Rai Widjaja, 2007: 38). KUHPerdata tidak mengatur secara jelas bahwa pendirian Maatschap harus dilakukan dengan akta notaris, Akta Notaris boleh tidak dibuat dan cukup hanya berdasarkan perjanjian di antara para pendirinya saja. Bahkan dapat didirikan dengan perjanjian secara lisan untuk mencapai persetujuan kehendak (Gatot Supramono, 2007:14)

Pendirian persekutuan perdata melalui perjanjian itu haruslah memenuhi syarat sahnya perjanjian sebagaimana ditentukan dalam Pasal 1320 KUHPerdata yaitu kesepakatan para pihak, kecakapan, objek yang diperjanjikan dan sebab yang halal. Syarat kesepakatan dan kecakapan merupakan syarat subjektif yang menyangkut orang- orang yang membuat perjanjian, sedangkan syarat objek dan sebab yang halal adalah syarat objektif yang menyangkut objek dari perjanjian (I Ketut Oka Setiawan, 2018:63).

Jika dibandingkan dengan perkumpulan biasa, pada hakikatnya Persekutuan Perdata tidaklah berbeda dengan perkumpulan biasa, hanya saja pada persekutuan perdata haruslah ada tujuan untuk memperoleh keuntungan sedangkan pada persekutuan lain tidak diharuskan untuk memperoleh keuntungan, selain 
itu pada persekutuan perdata, pemasukan merupakan unsur yang mutlak harus dipenuhi, yang berupa pemasukan barang, uang dan tenaga (Gatot Supramono, 2007:16).

\section{Pengaturan Pendaftaran Badan Usaha melalui Sistem Administrasi Badan Usaha (SABU)}

Pada tanggal 12 Juli 2018, pemerintah telah menerbitkan Peraturan Menteri Hukum dan Hak Asasi Manusia Nomor 17 Tahun 2018, tentang Pendaftaran Persekutuan Komanditer, Persekutuan Firma dan Persekutuan Perdata. Seperti yang telah kita bahas pada subbab sebelumnya,bahwa untuk badan usaha bukan badan hukum seperti CV, Firma dan Persekutuan Perdata berlaku ketentuan KUHPerdata dan KUHD dimana pendiriannya dengan akta Notaris dan dilakukan pendaftaran cukup di Kepaniteraan Pengadilan Negeri setempat. Akan tetapi, dengan adanya Permenkumham No. 17/2018 tersebut Pemerintah mewajibkan bagi badan usaha bukan badan hukum tersebut untuk melakukan pendaftaran badan usahanya kepada Menteri. Permenkumham No. 17/ 2018 juga memberikan definisi atas istilah CV, Firma dan Persekutuan Perdata yang dulunya definisinya diatur dalam KUHD dan KUHPerdata. Definisi $\mathrm{CV}$ menurut pasal 1 angka 1 Permenkumham No. 17/2018 adalah persekutuan yang didirikan oleh satu atau lebih sekutu komanditer dengan satu atau lebih sekutu komplementer, untuk menjalankan usaha secara terus menerus. Pengertian Firma menurut pasal 1 angka 2 adalah persekutuan dimana sekutunya berhak bertindak mewakili persekutuan. Adapun yang dimaksud dengan Persekutuan Perdata berdasarkan ketentuan pasal 1 angka 3 adalah persekutuan yang menjalankan profesi dimana para sekutu dapat mewakilui diri sendiri, dan memiliki tanggung jawab terhadap pihak ketiga.

$$
\text { Berdasarkan }
$$

Permenkumham No. 17/2018, permohonan pendaftaran $\mathrm{CV}$, Firma dan Persekutuan Perdata diajukan kepada Menteri melalui Sistem Administrasi Badan Usaha (SABU). Sebagaimana ketentuan pasal 1 angka 5 Permenkumham No. 17/2018, Sistem Administrasi Badan Usaha adalah pelayanan jasa teknologi informasi badan usaha secara elektronik yang diselenggarakan oleh Direktorat Jenderal Administrasi Hukum Umum.

Dengan adanya SABU, pendirian $\mathrm{CV}$, Firma dan Persekutuan Perdata tidak lagi sesederhana sebagaimana diatur dalam KUHPerdata dan KUHD, akan tetapi harus melalui proses permohonan pengajuan nama melalui SABU. Satu hal yang sangat penting dalam hal ini adalah bahwa pengajuan nama tersebut harus memenuhi persyaratan bahwa nama tersebut belum pernah dipakai secara sah oleh CV, Firma dan Persekutuan 
Perdata lain dalam SABU. Permohonan pengajuan nama $\mathrm{CV}$, Firma dan Persekutuan Perdata ini dikenai biaya sesuai dengan ketentuan perundangundangan yang berlaku dibidang penerimaan negara bukan pajak (PNBP). Persetujuan atau penolakan atas permohonan pemakaian nama CV, Firma dan Persekutuan Perdata ini nantinya akan disetujui oleh Menteri secara elektronik. Untuk pemakaian nama CV, Firma dan Persekutuan Perdata yang telah disetujui, nantinya akan berlaku untuk jangka waktu paling lama 60 (enam puluh) hari. Setelah pengajuan nama disetujui oleh Menteri baru kemudian pendirian $\mathrm{CV}$, Firma dan Persekutuan Perdata dibuat dengan Akta Notaris.

Pendaftaran CV, Firma dan Persekutuan Perdata yang menurut KUHD didaftarkan di Kepaniteraan Pengadilan Negeri setempat, sejak adanya Permenkumham No. 17/2018 ini harus didaftarkan melalui SABU dalam jangka waktu selambatnya 60 (enam puluh) hari dari pendirian $\mathrm{CV}$, Firma dan Persekutuan Perdata yang dibuktikan dengan akta notaris. Sebagai bukti bahwa CV, Firma dan Persekutuan Perdata telah didaftarkan kepada Menteri, Menteri kemudian akan menerbitkan Surat Keterangan Terdaftar (SKT) secara elektronik. SKT adalah tanda bukti yang diterbitkan oleh menteri Hukum dan HAM atas pendaftaran CV, Firma dan Persekutuan Perdata.
Pendaftaran terhadap $\mathrm{CV}$, Firma dan Persekutuan Perdata melalui SABU tidak hanya dilakukan pada saat pendirian badan usaha bukan badan hukum tersebut, akan tetapi juga berlaku pada saat adanya perubahan anggaran dasar perseroan Komanditer, Persekutuan Perdata, dan Perseroan Firma tersebut. Ketentuan mengenai tata cara permohonan pendaftaran dan pendirian CV, Firma dan Persekutuan Perdata berlaku pula dalam hal pendaftaran perubahan anggaran dasar yang berupa akta perubahan perseroan tersebut.

\section{Dualisme Pengaturan Mengenai Badan Usaha Bukan Badan Hukum Dalam Peraturan Perundang- Undangan Di Indonesia.}

Seperti yang telah dibahas sebelumnya, bahwa pengaturan mengenai pendirian dan pendaftaran badan usaha bukan badan hukum yaitu $\mathrm{CV}$ dan Firma diatur dalam pasal 16-35 KUHD dan pendirian Persekutuan Perdata diatur dalam pasal 1618-1646 KUHPerdata, akan tetapi dengan terbitnya Permenkumham No. 17/2018 maka pengaturan mengenai pendirian dan pendaftaran CV, Firma dan Persekutuan Perdata turut diatur dalam Permenkumham tersebut. Kemudian yang menjadi pertanyaan disini adalah apakah Permenkumham No. 17/2018 kemudian dengan serta merta dapat mencabut keberlakuan dari 
pengaturan $\mathrm{CV}$, Firma dan Persekutuan Perdata sebagaimana diatur dalam KUHD dan KUHPerdata.

Perlu digarisbawahi bahwa Permenkumham No. 17/2018 tidak mencabut keberlakukan pengaturan pendirian dan pendaftaran CV, Firma dan Persekutuan Perdata sebagaimana diatur dalam pasal 23 KUHD dan 1618 KUHPerdata sebab tidak ada satupun klausula dalam Permenkumham No. 17/2018 yang mencabut keberlakuan pasal- pasal yang mengatur CV, Firma, dan Persekutuan Perdata dalam KUHD dan KUHPerdata. Hal ini kemudian menyebabkan adanya dualisme pengaturan mengenai pendirian dan pendaftaran $\mathrm{CV}$, Firma dan Persekutuan Perdata dalam peraturan perundangundangan di Indonesia.

Jika dibandingkan dengan pengaturan Perseroan Terbatas yang dulunya juga sempat diatur dalam KUHD, kemudian pada tanggal 7 Maret 1995 terbitlah Undang - Undang Nomor 1 Tahun 1995 tentang Perseroan Terbatas. Pada UUPT No. 1/1995 pasal 128 ayat (1) menentukan bahwa dengan berlakunya undang- undang tersebut maka ketentuan pasal 36 sampai dengan pasal 56 KUHD yang mengatur mengenai perseroan terbatas berikut perubahannya terakhir dengan UU No. 4 Tahun 1971 tentang Perubahan dan Penambahan atas Ketentuan Pasal 54 KUHD dinyatakan tidak berlaku. Pada UUPT No. 1/1995 itu jelas, bahwa ketentuan mengenai perseroan terbatas pada KUHD dicabut dan diganti dengan berlakunya UUPT No. 1/1995 tersebut sehingga secara otomatis ketentuan KUHD sepanjang mengatur mengenai PT tidak lagi berlaku.

Apabila kemudian kita lihat kembali ketentuan Permenkumham No. 17/2018, bahwa peraturan menteri tersebut lahir karena diperintahkan oleh Peraturan Pemerintah Nomor 24 Tahun 2018 tentang Pelayanan Perizinan Berusaha Terintegrasi Secara Elektronik, dan PP No. 24/2018 tersebut dibuat dalam rangka mempercepat dan meningkatkan penanaman modal dan berusaha dengan menerapkan pelayanan perijinan berusaha secara elektronik sebagai pelaksanaan dari pasal 25 Undang- undang Nomor 25 Tahun 2007 tentang Penanaman Modal. Permenkumham No. 17/2018 ini tidak menunjuk sedikitpun ketentuan CV, Firma dan Persekutuan Perdata yang diatur dalam KUHD dan KUHPerdata.

Jika dilihat dari sejarah diterbitkannya Permenkumham No. 17/ 2018 tersebut beserta PP dan UU yang memerintahkan terbitnya Permenkumham No. 17/2018 tersebut maka dapat kita ketahui bahwa ketentuan mengenai pendirian dan pendaftaran CV, Firma dan Persekutuan Perdata sebagaimana diatur dalam pasal 16-35 KUHD dan pasal 1618 dan 1646 tidak pernah dicabut, sehingga secara hukum ketentuan mengenai $\mathrm{CV}$, Firma 
dan Persekutuan Perdata dalam KUHD dan KUHPerdata juga masih berlaku sampai dengan saat ini. Masih berlakunya ketentuan mengenai badan usaha bukan badan hukum dalam pasal 16-35 KUHD dan pasal 1618 dan 1646 KUHPerdata sekaligus juga berlakunya Permenkumham No. $17 / 2018$ yang mengatur hal yang sama menyebabkan adanya tumpang tindih peraturan perundang- undangan di bidang pendaftaran $\mathrm{CV}$, Firma dan Persekutuan Perdata.

Selain adanya tumpang tindih norma mengenai pendaftaran $\mathrm{CV}$, Firma dan Persekutuan Perdata akibat dualisme peraturan hukum tersebut, terdapat juga ketidaksesuaian (incompability) norma antara ketentuan pasal 23 KUHD dengan pasal 3 Permenkumham No. 17/2018, dimana Pasal 23 KUHD yang sampai saat ini masih berlaku mewajibkan adanya pendaftaran CV, Firma dan Persekutuan Perdata hanya sampai di Kepaniteraan Pengadilan Negeri, sedangkan pasal 3 Permenkumham No. 17/2018 menyatakan bahwa pendaftaran pendirian $\mathrm{CV}$, Firma dan Persekutuan Perdata diajukan kepada Menteri melalui sistem Administrasi Badan Usaha. Dualisme pengaturan yang menyebabkan tumpang tindih dan ketidak sesuaian norma ini tentu saja menimbulkan adanya suatu ketidakpastian hukum di masyarakat.

$$
\text { Pada dasarnya suatu }
$$
peraturan hukum akan dikatakan memiliki kepastian hukum apabila tidak multi tafsir, tidak menimbulkan keragu- raguan dan tidak menimbulkan kontradiksi serta kekaburan norma antara satu sistem norma dengan sistem norma yang lainnya. Menurut Gustav Radbruch bahwa kepastian hukum meliputi dua hal yaitu :

1. Kepastian oleh karena hukum;

2. Kepastian dalam atau dari hukum;

Kepastian oleh karena hukum maksudnya adalah bahwa hukum akan berguna dalam masyarakat apabila hukum dapat menjamin kepastian dalam masyarakat, sedangkan kepastian dalam atau dari hukum maksudnya bahwa hukum sebanyak- banyaknya adalah undang- undang yang mana ketentuan di dalamnya tidak terdapat adanya pertentangan. (E. Utrecht, 1959:26).

Kepastian hukum merupakan salah satu tujuan hukum. Tanpa adanya suatu kepastian hukum, masyarakat menjadi bingung dan tidak tahu apa yang harus diperbuat. Dalam dibentuknya suatu peraturan hukum, seringkali terjadi adanya suatu kegagalan produk hukum dalam memberikan kepastian hukum bagi masyarakat. Lon Fuller memberikan pendapat bahwa dalam bekerjanya hukum di dalam masyarakat ada delapan syarat yang harus dipenuhi oleh hukum itu sendiri yaitu:

1. Generalitas Undang- undang;

2. Pengumuman Undangundang; 
3. Undang- undang tidak boleh berlaku surut;

4. Jelasnya perumusan Undangundang;

5. Adanya konsistensi;

6. Undang- undang harus dapat dilaksanakan;

7. Undang- undang tidak diubah terlalu sering;

8. Adanya kesesuaian antara Undang- undang dan pelaksanaannya di masyarakat (Gunawan Widjaja, 2006: 2133).

Adanya tumpang tindih dan ketidaksesuaian norma antara pasal 23 KUHD dengan Pasal 3 Permenkumham No. 17/2018 menimbulkan adanya suatu ketidakpastian hukum. Ketidakpastian hukum ini salah satunya diakibatkan oleh karena tidak terpenuhinya syarat kedua dari teori kepastian hukum menurut Gustav Radburch yaitu kepastian dalam atau dari hukum, dimana dalam suatu ketentuan undang- undang tidak boleh terdapat suatu pertentangan. Selain itu penyebab terjadinya ketidakpastian hukum ini dikarenakan Permenkumham No. 17/2018 ini tidak memenuhi desiderata kelima dari Lon Fuller, dimana suatu peraturan perundang- undangan yang tidak sejalan dan bertentangan satu dengan lainnya akan menyebabkan undang- undang tersebut tidak dapat dilaksanakan oleh masyarakat. Masyarakat menjadi bingung mana ketentuan hukum yang harus ditaati. Inkonsistensi tidak hanya dapat diartikan sebagai adanya pertentangan (repugnant) tetapi juga kontradiksi (contradictive), ketidaksesuaian (incompatibility) dan ketidak sejalanan (incomvenience) (Lon L. Fuller, 1964: 64).

Dalam hal terjadinya tumpang tindih dan ketidaksesuaian (incompatibility) antara satu peraturan hukum dengan peraturan hukum yang lain maka dapat dilakukan penyelesaian konflik norma dengan asas preferensi yaitu :

1. Asas lex superior derograt legi inferior, yaitu aturan yang lebih tinggi mengesampingkan aturan yang lebih rendah;

2. Asas lex posterior derograt legi priori, yaitu hukum yang berlaku lebih belakangan menge-sampingkan hukum yang berlaku lebih dulu;

3. Asas lex specialis derograt legi generalis, yaitu hukum bersifat lebih mengkhusus mengesampingkan norma hukum yang lebih bersifat umum; (Budiono Kusumohamidjojo, 2016:161).

Terkait dengan adanya pertentangan antara pasal 23 KUHD dengan pasal 3 ayat 1 Permenkumham No. 17/2018 mengenai pendaftaran $\mathrm{CV}$, Firma dan KUHPerdata maka dalam penelitian karya tulis ilmiah ini penulis menggunakan asas lex posterior derograt legi priori, dimana aturan yang lebih tinggi akan mengesampingkan aturan yang lebih rendah.

Untuk mengetahui mana aturan yang lebih tinggi dan 
mana aturan yang lebih rendah, maka perlu dilihat terlebih dahulu hierarki peraturan perundang- undangan di Indonesia sebagaimana diatur dalam pasal 7 ayat (1) Undangundang Nomor 12 Tahun 2011 tentang Pembentukan Peraturan Perundang- Undangan yaitu :

a. UUD Tahun 1945;

b. TAP MPR;

c. Undang- Undang / Peraturan Pemerintah Pengganti

Undang- Undang;

d. Peraturan Pemerintah;

e. Peraturan Presiden;

f. Peraturan Daerah Provinsi;

g. Peraturan

Daerah

Kabupaten/Kota;

Dari ketujuh peraturan

perundang- undangan tersebut KUHD dan KUHPerdata disetarakan dengan Undang Undang oleh raja Belanda pada 16 Mei 1946 berdasarkan berdasarkan Staatblads $1847-23$. Kemudian berdasarkan pasal 1 Aturan Peralihan UUD 1945 yang menentukan "Segala peraturan perundang - undangan yang ada masih tetap berlaku selama belum diadakan yang baru menurut undang- undang dasar ini" maka KUHD dan KUHPerdata masih berlaku hingga saat ini di Indonesia. Jika dilihat dari hierarki peraturan perundang- undangan bahwa KUHD dan KUHP yang disetarakan dengan UndangUndang maka kedudukan KUHD dan KUHPerdata lebih tinggi dari Permenkumham No. 17 Tahun 2018. Hal ini juga sejalan dengan Stufenbau Theory dari Hans Kelsen yang menyatakan bahwa
"Peraturan perundangundangan yang lebih rendah apabila bertentangan dengan peraturan perundang- undangan yang lebih tinggi maka akan kehilangan kekuatan berlakunya" (Budiono Kusumohamidjojo, 2016, 130).

Oleh karena itu dengan adanya tumpang tindih dan ketidaksesuaian norma dalam hal pengaturan pendaftaran $\mathrm{CV}$, Firma,dan Persekutuan Perdata ini seharusnya ketentuan KUHD dan KUHPerdatalah yang berlaku karena bersifat lebih tinggi daripada Permenkumham No, 17/2018. Jika dikaji lebih lanjut adapun tujuan pemerintah menerbitkan Permenkumham No. 17/2018 ini adalah untuk menciptakan sistem perizinan berusaha bagi badan usaha bukan badan hukum yang tertata dengan rapi dan sistematis serta disesuaikan dengan perkembangan teknologi dan persaingan global. Hal ini sebetulnya bisa saja dilakukan tetapi dengan tetap memperhatikan ketentuanketentuan peraturan perundangundangan yang lebih tinggi dalam hal ini adalah KUHD dan KUHPerdata.

Apabila pemerintah merasa bahwa ketentuan dalam KUHD dan KUHPerdata telah tidak sesuai dengan perkembangan masyarakat pada saat ini, seharusnya terlebih dahulu dilakukan perubahan atau penggantian bahkan pencabutan terhadap ketentuan CV, Firma dan Persekutuan Perdata yang diatur dalam KUHD dan 
KUHPerdata tersebut dengan suatu peraturan perundangundangan yang sederajat yaitu Undang- undang, baru kemudian dilanjutkan dengan membuat Peraturan Pemerintah dan Peraturan Menteri yang mengkhusus mengenai CV, Firma dan Persekutuan Perdata yang sesuai dengan situasi dan kebijakan pemerintah saat ini sebagai pelaksanaan dari Undang- Undang perubahan atau pengganti KUHD dan KUHPerdata mengenai $\mathrm{CV}$, Firma dan Persekutuan Perdata tersebut.

\begin{tabular}{|c|c|c|}
\hline Akibat & Bagi & Badan \\
\hline Usaha & Badan & Hukum \\
\hline Tidak & Mend & laftarkan \\
\hline Dirinya & Pada & Sistem \\
\hline $\begin{array}{l}\text { Administrasi } \\
\text { (SABU) }\end{array}$ & Badan & Usaha \\
\hline Jika & kita & lihat \\
\hline
\end{tabular}

Permenkumham No. 17/2018 juga memiliki satu kelemahan yaitu tidak adanya pengaturan mengenai akibat hukum yang terjadi apabila suatu Badan Usaha bukan badan hukum yang berbentuk CV, Firma dan Persekutuan Perdata yang telah berdiri sebelum Permenkumham No. 17/2018 diundangkan tidak mendaftarkan dirinya dalam SABU. Ketentuan pasal 23 Permenkumham No. 17/2018 hanya menentukan bahwa bagi $\mathrm{CV}$, Firma dan Persekutuan Perdata yang telah terdaftar di Pengadilan Negeri, diberikan jangka waktu 1 (satu) tahun untuk melakukan pencatatan pendaftaran dalam sistem SABU dan diperbolehkan menggunakan nama yang sudah dipakai secara sah oleh CV, Firma dan Persekutuan Perdata yang sudah terdaftar dalam SABU. Dengan tidak adanya sanksi yang tegas, maka akan menimbulkan resiko adanya ketidaktaatan masyarakat terhadap Permenkumham No. 17/2018 ini.

Sebagaimana ditentukan pada pasal 4 Permenkumham No. 17/2018 bahwa permohonan pendaftaran CV, Firma dan Persekutuan Perdata ini diawali dengan pengajuan nama $C V$, Firma dan Persekutuan Perdata tersebut kepada Menteri. Oleh karena itu apabila dalam jangka waktu 1 (satu) tahun suatu CV, Firma dan Persekutuan Perdata yang telah berdiri tidak mendaftarkan dan mencatatkan CV, Firma dan Persekutuan Perdatanya dalam SABU, maka dapat dianggap bahwa terdapat konsekuensi dikemudian hari bahwa nama CV, Firma dan Persekutuan Perdata tersebut telah dipergunakan oleh $\mathrm{CV}$, Firma dan Persekutuan Perdata lainnya. Oleh karena tidak adanya sanksi hukum yang tegas terkait pendaftaran pendirian $\mathrm{CV}$, Firma dan Persekutuan Perdata dalam sistem SABU sesungguhnya telah membuktikan bahwa Permenkumham No. 17/2018 tidak dapat menegakkan kepastian hukum dimasyarakat.

\section{Kesimpulan}

Adapun kesimpulan yang dapat ditarik dari pemaparan pembahasan atas permasalahan diatas adalah sebagai berikut: 
1. Bahwa terdapat dualisme pengaturan mengenai pendaftaran badan usaha bukan badan hukum di Indonesia sebagaimana diatur dalam KUHD dan KUHPerdata serta dalam Permenkumham No. $17 / 2018$. Berdasarkan asas lex posterior derograt legi priori, KUHD dan KUHPerdata sebagai peraturan yang lebih tinggi setara dengan undang- undang mengesampingkan

Permenkumham No. 17/2018 sebagai peraturan yang lebih rendah, sehingga dalam hal terjadi dualisme pengaturan pendaftaran pendirian badan usaha bukan badan hukum maka yang dipergunakan adalah ketentuan dalam KUHD dan KUHPerdata.

2. Tidak ada sanksi hukum bagi Badan Usaha bukan badan hukum yang berbentuk CV, Firma dan Persekutuan Perdata tidak mendaftarkan dirinya dalam SABU. Dengan tidak adanya sanksi hukum tersebut membuktikan bahwa Permenkumham No. 17/2018 itu tidak dapat memberikan suatu kepastian hukum bagi masyarakat

\section{Saran}

Adapun yang dapat penulis sarankan terkait dengan pembahasan diatas adalah :

1. Bagi pemerintah

Agar dibuat Undang- undang sebagai perubahan atau pengganti atas KUHD dan KUHPerdata yang mengatur mengenai $\mathrm{CV}$, Firma dan Persekutuan Perdata secara mengkhusus yang disesuaikan dengan kondisi saat ini yang dapat mencakup juga mengenai perizinan berusaha yang terintegrasi secara online. Hal ini dikarenakan suatu Undang- Undang hanya dapat dirubah atau diganti dengan peraturan perundangundangan yang setingkat dengan Undang Undang, baru kemudian selanjutnya dibuatkan Peraturan Pemerintah dan Peraturan Menteri sebagai peraturan pelaksanaan dari undang undang tersebut agar tidak terjadi overlapping peraturan perundang- undangan.

2. Bagi masyarakat pemilik badan usaha bukan badan hukum agar tetap melaksanakan ketentuan KUHD dan KUPerdata sebagai peraturan yang lebih tinggi yang mengatur mengenai $\mathrm{CV}$, Firma dan Persekutuan Perdata di Indonesia mengingat secara hierarki hukum Permenkumham No. $18 / 2018$ yang mengatur mengenai CV, Firma dan Persekutuan Perdata tidak sesuai dan tidak sejalan dengan peraturan perundangundangan yang lebih tinggi.

\section{Daftar Pustaka}

Buku :

E. Utrecht, 1959, Pengantar dalam Hukum Indonesia, Cetakan Keenam, PT. Penerbit Balai Buku Ihtiar, Jakarta.

Ibrahim, Johannes, 2013, Hukum Organisasi Perusahaan, Pola 
Kemitraan dan Badan Hukum, PT. Refika Aditama, Bandung. Lon L. Fuller, 1964, Morality of Law, Yale University Press, London. Kusumohamidjojo, Budiono, 2016, Teori Hukum Dilema Antara Hukum dan Kekuasaan, Yrama Widya, Bandung.

Muhammad, Abdulkadir, 1999, Hukum Perusahaan Indonesia, PT. Citra Aditya Bhakti, Bandung.

R., Salimar, Abdul, S.H., M.H., 2005, Hukum Bisnis Untuk Perusahaan, Teori dan Contoh Kasus, Kencana Prenada Media Grup, Jakarta.

Setiawan, I Ketut Oka, 2018, Hukum Perikatan, Sinar Grafika, Jakarta.

Simatupang, Richard Burton 2007, Aspek Hukum Dalam Bisnis, PT. Rineka Cipta, Jakarta.

Supramono, Gatot ,2007, Kedudukan Perusahaan Sebagai Subjek Dalam Gugatan Perdata, PT. Rineka Cipta, Jakarta.

Sukirno, Sadono, Dkk., 2017, Pengantar Bisnis, Kencana, Jakarta.

Widjaja, I. G. Rai, 2007, Hukum Perusahaan, MegaPoin, Jakarta.

\section{Jurnal}

Widjaja, Gunawan 2006, "Lon Fuller, Pembuatan. Undang.Undang dan Penafsiran Hukum", Law Review: Fakultas Hukum Universitas Pelita Harapan,; Vo. VI, No. 1, Juli 2006.

\section{Peraturan Perundang- Undangan}

Undang-undang Dasar Negara Republik Indonesia Tahun 1945.

Kitab Undang - Undang Hukum Perdata.

Kitab Undang - Undang Hukum Dagang.

Undang- Undang Republik Indonesia Nomor 3 Tahun 1982 tentang Wajib Daftar Perusahaan (Lembaran Negara Republik Indonesia tahun 1982 Nomor 7, Tambahan Lembaran Negara Republik Indonesia Nomor 3214).

Undang- Undang Republik Indonesia Nomor 25 Tahun 2007 tentang Penanaman Modal (Lembaran Negara Republik Indonesia Tahun 2007 Nomor 67, Tambahan Lembaan Negara Republik Indonesia Nomor 4724)

Undang- Undang Republik Indonesia Nomor 40 Tahun 2007 tentang Perseroan Terbatas (Lembaran Negara Republik Indonesia Tahun 2007 Nomor 106, Tambahan Lembaran Negara Republik Indonesia Nomor 4756).

Peraturan Pemerintah Republik Indonesia Nomor 24 Tahun 2018 tentang Pelayanan Perizinan Berusaha Terintegrasi Secara Elektronik, Lembaran Negara Republik Indonesia Tahun 2018 Nomor 90, Tambahan Lembaran Negara Republik Indonesia Nomor 6215)

Peraturan Menteri Hukum dan Hak Asasi Manusia Republik Indonesia Nomor 17 Tahun 2018 tentang Pendaftaran 


Persekutuan Komanditer, Persekutuan Perdata.

